\title{
artículos
}

\section{Generación del 27: Pintura, música y poesía}

\author{
Javier García-Luengo Manchado \\ Universidad de Salamanca
}

\begin{abstract}
RESUMEN
En este artículo se analiza la relación personal y estética existente entre algunos de los músicos, pintores y poetas vinculados a la conocida como Generación del 27, entendiéndose ésta como un Grupo caracterizado por la interdisciplinaridad artística e ideológica. Asimismo, se analizan las consecuencias estéticas desarrolladas a partir de estos vínculos. PALABRAS ClAVE: Generación del 27/ Surrealismo/ Poesía/ Música/ Pintura.

27 's Generation: Painting, Music and Poetry

ABSTRACT

This article is to discuss the relationship between diferents musicians, painters and poets linked by Generación del 27. This Group is characterized by the important relations between diferents arts and ideologys. His influences and features are also analysed. KEY WORDS: 27's Generation/ Surrealism/ Poetry/ Music/ Painting.
\end{abstract}

Tal y como ha justificado John Crispin, uno de los hechos irrefutables que mejor pueden definir las vanguardias $o$ al proceso de modernización estética europea durante el primer tercio del siglo XX, es la voluntad consciente de interrelación artística e intelectual $^{1}$. En efecto, aunque en alguna ocasión la historiografía ha insistido en demostrar la unión existente entre poesía, música y pintura a lo largo de los siglos, lo cierto es que en muchos casos dicha relación se asienta no tanto en la intención de generar un diálogo consciente entre las musas para crear un arte distinto, como en la respuestas que desde diferentes ámbitos estéticos se dará a una situación histórica y cultural común, respuestas que precisamente al emanar de un mismo manantial se hacen relacionables.

Así, por ejemplo, en la España del Sigo de Oro, se pueden relacionar los escritos de Santa Teresa con la polifonía de Tomás Luís de Victoria y los monjes de Zurbarán, de hecho, en estos autores la veta mística es innegable, pero su arte, su hacer, desde mi punto de vista, es la respuesta a un momento determinado, sin que haya una voluntad consciente de desarrollar una estética conjunta, de juego común para crear un arte diferente. Por otra parte además hay que tener en cuenta que el estatus del artista en los siglos XVI o XVII poco tiene que ver con el que se desarro-

* GARCÍA-LUENGO MANCHADO, Javier: "Generación del 27: Pintura, música y poesía”, en Boletín de Arte, n 30-31, Departamento de Historia del Arte, Universidad de Málaga, 2009-2010, págs. 287-300. Fecha de recepción: Junio de 2009.

1 CRISPIN, J.: La estética de las Generaciones de 1925: Vanguardia, Modernismo y Primitivismo popular; en AA.VV.: El universo creador del 27: literatura, pintura, música y cine. Actas del X Congreso de Literatura Española Contemporánea, Málaga, Universidad de Málaga, 1997, págs. 15 y ss. 
llará en el mundo contemporáneo.

No obstante, aunque la prosecución de la obra de arte total se ha buscado de manera directa o indirecta a lo largo de la historia, lo cierto es que será el romanticismo el que siente de una forma real esta tendencia y quizá uno de los ejemplos más destacados sea la concepción operística de Wagner, donde literatura, música y escenografía se unen para generar unas creaciones estéticas que incluso supongan un modo de entender la vida, no en vano la carga ideológica en la creación wagneriana es muy importante.

Pues bien, con el arte de los primeros decenios del siglo XX, hijo del romanticismo, aquellos presupuestos van a llegar a su eclosión, con la peculiaridad de que también gracias al movimiento romántico y a la ilustración, a estas alturas el artista había alcanzado un estrato intelectual muy importante, tanto desde el punto de vista ético como del estético.

Indudablemente, el fenómeno que mejor puede definir el arte del primer tercio del siglo XX son las Vanguardias y con ellas el continuo deseo de modernidad, y si bien es cierto que en muchos casos definimos la vanguardia como un grupo o unos grupos de creadores cohesionados, unidos por un manifiesto, por el correspondiente órgano de difusión, y, claro está, por un repertorio ideológico y formal común, no menos cierto es que otro factor que caracteriza a la vanguardia por antonomasia es la voluntad de interrelación con las artes. Qué duda cabe que buena parte de la estética de la vanguardia -pintura y escultura- se genera por su relación con otras manifestaciones, incluso podemos decir que la irrupción de la fotografía y el cine aceleraron de algún modo su aparición. Así, por ejemplo, la cronofotografía y el cine suscitarán la estética del Futurismo. Pero tampoco el cine se podrá entender sin su relación con lo pictórico. Del mismo modo el collage cubista será esencial para la superposición fílmica del cine ruso, como en general también serán definitorios los ritmos musicales para todo el cine de vanguardia de los veinte y treinta.

Y qué decir de la escenografía, arte éste que tendrá por ahora un desarrollo sin precedentes gracias precisamente a ese diálogo entre Musas, ahí está el impacto de los famosos Ballets Rusos de Diaghilev. Así pues, a tenor de lo expuesto, el arte del primer tercio de siglo, del que somos herederos directos, no se puede entender sin tener en cuenta la interrelación artística consciente.

Pero quizá uno de los hechos más destacados por lo que a música y artes plásticas se refiere, es que gracias a la música se llegó a la abstracción, o al menos a un tipo de abstracción. Hay que recordar que para los años diez se "rozará" la abstracción desde diferentes ámbitos, el cubismo analítico, los experimentos de E. Nolde, etc.

Pero la experiencia de abstracción y música más importante vendrá de la mano de W. Kandinsky, quien precisamente tras la audición de una ópera de Wagner, plantea una nueva teoría artística: si la música con sus propios medios, sin la necesidad de imitar, podía llegar a conmover, ¿por qué la pintura debía supeditarse a la naturaleza para emocionar? A partir de entonces Kandinsky comienza desarrollar una pintura basada exclusivamente en los medios expresivos de ésta: 
forma y color ${ }^{2}$. En 1911 efectúa su primera acuarela abstracta. Desde aquel momento su evolución artística quedará marcada por la música, como bien demuestran algunas de sus series más destacadas: improvisaciones y composiciones. Del mismo modo su trayectoria seguirá muy de cerca el hacer de Schöenberg y el Dodecafonismo, con una serie de influencias más que evidentes.

Así pues, es en este contexto donde se ubica el trabajo común de las artes en busca de la modernidad que en España se va a llevar a cabo en torno a la Generación del 27.

Llegados a este punto, debo hacer unas precisiones sobre el título elegido y que, por tanto, nos servirán para delimitar esta intervención. El término Generación del 27, proviene de la historiografía literaria y ha sido, y aún es, un nombre muy discutido. En primer lugar por lo que a la aplicación metodológica derivada de las propuestas de Ortega y Marías refiere ${ }^{3}$. En este caso se trataría de una promoción de poetas, nacidos entre finales del XIX y principios del XX, que tiene una formación similar y un hecho común que aglutina su estética, la celebración del tricentenario de Góngora en 1927, tal conmemoración, no es un mero pretexto, era una toma de postura estética que reclamaba el culteranismo, con todas las consecuencias que este hecho tuvo en la producción artística de entonces.

Más allá de las discusiones generadas en el entorno de la historia de la literatura, con el paso del tiempo han sido muchos los autores que desde diversas disciplinas entienden el 27 como elemento catalizador de un momento cultural, por eso prefieren hablar más que de Generación, de Grupo, y no sólo de poetas, sino de grupo en el que se van a dar cita creadores de diversas disciplinas artísticas e intelectuales ${ }^{4}$.

Dicho Grupo se inserta en un contexto más amplio, la Edad de Plata, término este defendido por Jover Zamora y Mainer ${ }^{5}$, que iría desde aproximadamente 1900 a 1936, caracterizado por la convivencia de diferentes generaciones, siendo un momento de una brillantez extraordinaria en todos los campos, donde coexisten autores de la valía y la disparidad de Azorín, Unamuno con Lorca o Cernuda, Zuloaga y Dalí. En definitiva se trata de una superposición generacional que representará el paso de la

\footnotetext{
2 KANDINSKY, W.: De lo espiritual en el arte, Barcelona, Enlace, 1973.
}

3 MARÍAS, J.: Generaciones y Constelaciones, Madrid, Alianza, 1989; ORTEGA Y GASSET, J.: Ensayo sobre la "Generación del 98" y otros escritores españoles contemporáneos, Madrid, Revista de Occidente, 1988.

4 En torno al problema de definición de la Generación del 27, así como de sus procesos estéticos e históricos, ver: ANDERSON, A. A.: El Veintisiete en tela de juicio: examen de la historiografía generacional y replanteamiento de la vanguardia histórica española, Madrid, Gredos, 2005; DÍEZ DE REVENGA, F. J.: Las Vanguardias y la Generación del 27, Madrid, Síntesis, 2004; HERNÁNDEZ PÉREZ, P.: La orientación surrealista en la Generación del 27, Zaragoza, Universidad de Zaragoza, 1987; MAINER, J. C.: La Edad de Plata (1902-1939): ensayo de interpretación de un proceso cultural, Madrid, Cátedra, 1993; MARTÍN OÑATE, A.: La Generación del 27: sus orígenes y sus protagonistas. Málaga, Diputación de Málaga, 1999; AA.VV.: Imágenes para una Generación poética (1918-1927-1936). Madrid, Consejería de Educación, Madrid, 1998; AA.VV.: La Generación del 27 desde dentro, Madrid, Istmo, 1987.

5 JOVER ZAMORA, J. M. (Dir.): La edad de plata de la cultura española, Historia de España Menéndez Pidal, Madrid, Espasa-Calpe, T. 39, 1989; MAINER, J. C.: La Edad de Plata (1902-1939): ensayo de interpretación de un proceso cultural, Madrid, Cátedra, 1993. 
tradición a la modernidad. No menos discusiones se han generado en torno a la fecha que da nombre a la Generación del 27. Como sabemos, en 1927 se celebraba el tricentenario del nacimiento de Góngora, con tal motivo los poetas considerados tradicionalmente como veintisietistas ofrecieron en Sevilla un homenaje al poeta cordobés, lo que suponía también un homenaje al culteranismo con todo lo que esto llevaba de implícito en torno al ideario estético de aquellos jóvenes.

Otros autores consideran poco representativo este hecho y han propuesto fechas alternativas, como la de 1925 , el propio Cernuda se decantó por ella 6 . Cierto es que desde el punto de vista artístico es muy significativo, pues es cuando se celebra la famosa Exposición de Artistas Ibéricos, considerado por la historiografía como punto de arranque del arte moderno en España, pero también es el año que reciben el premio Nacional de Literatura, R. Alberti por Marinero en Tierra y el Nacional de Música, Ernesto Halffter por su Sinfonieta.

También se han barajado otros nombres, como Generación de la República, pues ciertamente la llegada de la República es un hecho extraordinariamente relevante por aquel entonces. Por otra parte, la mayor parte de estos artistas de un modo u otro mostraron su compromiso ideológico y/o estético con la causa republicana.

En cuanto al término Generación de la Amistad, qué duda cabe que entre todos ellos existía una franca camaradería, pero no sólo entre poetas, sino entre pintores, músicos, intelectuales, amistad que además tuvo unas consecuencias estéticas, como veremos, evidentes ${ }^{7}$.

A la luz de lo expuesto, lo cierto es que a día de hoy es comúnmente aceptado por la historiografía que el 27 es un fenómeno que trasciende lo meramente poético, ahí está, por ejemplo, el congreso El Universo Creador del 27: literatura, pintura, música y cine, organizado por la Universidad de Málaga en 1997, o la exposición organizada en ese mismo año titulada la Generación del 27: artistas de Preguerra, así como, por lo que a música se refiere, hay que destacar la exposición y magnífico catálogo: La Música en la Generación del 27, organizado por el Ministerio de Cultura en $1986^{8}$. Todos estos estudios son punta de lanza que han sentado las bases para hablar de una literatura, una poesía, un arte y una música vinculadas con el 27 , al entroncarse todas estas manifestaciones en una estética y una ideología común, surgida a partir de la clara voluntad de interrelación como hecho estético ineludible y característico de la modernidad, modernidad que tanto anhelaban y buscaban aquellos artistas, modernidad que, por otra parte, identifica claramente su producción.

No obstante, estas consideraciones quizá también las podamos hacer porque en muchos casos el 27 es una actitud, una actitud ante la vida, ante la política, ante

6 CERNUDA, L.: “Generación de 1925”, en Obra Completa. Prosa I. Madrid, Siruela, págs. 183 y ss.

7 Sobre otros nombres barajados para definir a la Generación del 27, cfr.: GARCíA POSADA, M.: Acelerado sueño: memoria de los poetas del 27, Madrid, Espasa-Calpe, 1999.

8 AA.VV.: El universo creador del 27: literatura, pintura, música y cine, Málaga, Congreso de Literatura Española Contemporánea, 1996; AA.VV.: Generación del 27: artistas de Preguerra, Sevilla, Caja de San Fernando y Jerez, 1997; AA.VV.: La Música en la Generación del 27: homenaje a Lorca, 1915-1939, Madrid, Ministerio de Cultura, 1989. 
la historia y, por supuesto, ante el arte, en donde todos ellos encontraron una regeneración para todo lo demás. Se trataba de un grupo joven, divertido, que dejan a un lado las telarañas recalcitrantes del pasado para mirar al futuro con frescura, jovialidad y compromiso, pero lejos de renunciar a la tradición, encontrarán en ella el alimento para su modernidad. De hecho, el Veintisiete, tanto en literatura como en pintura o música, recogió la importante veta abierta por la vanguardia europea, mas lejos de asimilarla como una mera imitación, la convirtieron en algo propio.

Son muchos los rasgos comunes que se registran entre los componentes de este grupo, en primer lugar, comenzando por sus orígenes, buena parte de ellos proceden de provincias, arribando hasta la capital de España con el fin de estudiar o desarrollar su campo artístico. Así García Lorca llega desde Granada, Cernuda de Sevilla o Alberti desde Cádiz. Entre los pintores hay que destacar a Gregorio Prieto, procedente de La Mancha, B. Palencia de Albacete, Maruja Mallo de Galicia, Manuel Ángeles Ortiz de Granada y en escultura podemos hablar de A. Sánchez, cuyos orígenes se encuentran en Toledo. Por lo que a músicos respecta, debemos citar primeramente al gaditano M. de Falla, pues aunque en sentido estricto no pertenecería a esta generación, recordemos que nace en 1876, sin embargo, como tendremos la ocasión de comprobar, Falla era considerado todo un maestro por aquella Generación. También hay que citar a, por ejemplo, Fernando Remacha oriundo de tierras Navarras. No obstante, en música hay más excepciones, destacando en este sentido el llamado Grupo de Barcelona, con compositores como R. Gherard.

Por tanto, Madrid va a ser el centro para el desarrollo de estas nuevas inquietudes, pero además es que estos jóvenes trasportarán lo nuevo, lo culto, a sus lugares de origen, una empresa ciertamente ardua, pensemos que estamos en una España con unos índices de analfabetismo y hambruna extraordinarios. Pero, del mismo modo, también llevarán hasta la metrópoli cultural madrileña el impresionante acervo popular español.

Lo popular va a ser un hecho consustancial en la producción de todos estos jóvenes creadores. Lo popular entendido en su dimensión estética pero también en su dimensión ideológica, recordemos que muchos de estos artistas tendrán un compromiso político determinado donde el pueblo como tal tendrá unas connotaciones muy concretas.

Para comprender la adecuación y la inserción de los repertorios populares en la cultura de entonces, hay que conocer cuál era el panorama artístico español.

Como sabemos, la introducción en España de las poéticas de vanguardia se produce bastante tarde si tenemos en cuenta las dimensiones que este fenómeno había alcanzado en países como Francia, Alemania o Italia. Por tanto, cuando comienza a introducirse o a desarrollarse en España el conocido como arte nuevo, éste va a coincidir con el famoso Rappel al ordre, la llamada al orden, es decir ese fenómeno estético que tras la Gran Guerra se implanta en Europa, retomándose la tradición desde la depuración, desde los presupuestos formales heredados de la vanguardia; se mira al clasicismo con ojos nuevos ${ }^{9}$. 
De este modo, en España, la modernidad que se conozca no va ser la más revolucionaria anterior a la Gran Guerra, sino que lo más difundido será una figuración vista a través de los ojos de un cubismo más sencillo y comprensible, lo que se ha denominado como neocubismo o cubismo clasicista, y este tipo de arte será el que imponga Daniel Vázquez Díaz a principio de los veinte y del que se contagiará buena parte de los jóvenes creadores de entonces, como el propio Benjamín Palencia o Gregorio Prieto.

Pero ¿dónde van encontrar estos jóvenes esa nueva forma de aprehender la realidad depurada, esa forma de ver que llegaba desde París? Pues paradójicamente, la encontrarán en España, en lo popular y así Gregorio Prieto, conociendo claro está la esencia del cubismo -está en París en 1925-, girará la mirada hacia su tierra, hacia los pueblos de La Mancha para hallar la depuración formal, la austeridad cromática; se encuentra la modernidad en lo popular, insertándose de esta manera en los repertorios europeos.

Esto también lo hallaremos en la poesía, es tiempo ahora de hacer algo nuevo, de imponerse a los criterios heredados de la tradición finisecular, se rescatan formas como el romance, la copla o la seguidilla, quizá en este sentido la obra más representativa es el famoso Romancero Gitano, publicado por García Lorca en 1928. Pero no sólo en lo formal, no sólo se retoma la tradición en sus formas sino en su fondo, en su contenido, sus historias, sus ritmos están extraídos de las facciones más populares de la España de entonces. Quien ya fue un abanderado de esa convivencia entre tradición y modernidad fue Manuel de Falla. En sentido estricto, como ya he dicho, Manuel de Falla no se puede considerar miembro de esta Generación si la entendemos dentro de los cánones planteados por Ortega y Marías, sin embargo, el magisterio de Falla es abrumador en todo el grupo, no solo entre los músicos, también entre pintores y escritores y ello se debe en buena medida a esa referida amistad que tan bien define a la convivencia artística de entonces y a la admiración que los jóvenes le profesan.

Esta admiración emanaba de la gran personalidad artística del músico, recordemos que Falla había recopilado extraordinarios éxitos en Francia y su obra estaba plenamente imbricada en los circuitos de la modernidad europea al mismo nivel que Stravinsky o Debussy, Falla era el espejo donde se miraban los jóvenes. La generosidad, genialidad y modernidad del gaditano hace que se requiriese su presencia en las actividades que por entonces efectuaban aquellos creadores. De la misma manera, Falla se encargaba de que los nuevos creadores estuviesen allí donde él fuera.

En este sentido es muy interesante la gran amistad mantenida entre Lorca y Falla, especialmente desde que el gaditano se instalase en Granada, Falla, y esto es

9 Sobre el desarrollo del Arte Nuevo en y la recepción del Rappel al Ordre en España, resulta de imprescindible consulta los numerosos estudios del Profesor Carmona Mato referidos al tema, entre ellos: CARMONA MATO, E.: “El arte 'nuevo' y los 'nuevos realismos' en España, 1911-1936”; en Ángeles Santos. Un mundo insólito en Valladolid, Madrid, Patio Herreriano, Residencia de Estudiantes, 2003, págs. 90 y ss; y "Novecentismo y vanguardia en las artes plásticas españolas, 1906-1926"; en La Generación del 14 entre el Novecentismo y la Vanguardia (1906-1926), Madrid, Fundación Cultural MAPFRE, 2002, págs. 13-67. 
bien significativo, trabajará en la modernidad más puntera desde Granada. En torno a él se aglutinará un importante grupo de artistas y poetas con similares inquietudes, destacando, Hermenegildo Lanz, Manuel Ángeles Ortiz y el propio Lorca.

Manuel de Falla será, por tanto, el adalid de ese entronque de la modernidad con la tradición o, mejor dicho, todo un maestro en hallar la modernidad a partir de la tradición. Hasta cierto punto el compositor gaditano representará la superación de un nacionalismo musical que extraía literalmente melodías populares y las insertaba en los repertorios sinfónicos, para estudiar en profundidad el folclore, tomando aquellos repertorios no como una curiosidad, no como una copia más o menos armonizada, sino convirtiéndolo en elemento inspirador.

En esto Falla también antecederá a la pintura, pues frente al romanticismo populista que plasmaba lo anecdótico como un mero exotismo, la vanguardia española encontraría en lo popular todo un nuevo campo estético capaz de renovar la creación plástica contemporánea.

Uno de los primeros ejemplos donde apreciamos esa inserción tan característica de Falla, será en la Vida Breve, compuesta en 1905, aunque estrenada en 1914, una obra cargada de inspiración folclórica -sobre todo en la versión del 1914-, pero que une a su bagaje impresionista parisino, sentando las bases de su ulterior producción.

Manuel de Falla es el introductor de la modernidad musical en España y es considerado como tal allende los Pirineos. Amigo de Dukas, Ravel, Debussy o Stravinsky, el maestro gaditano asimila y proyecta la música de vanguardia en España y Europa. En cierto modo también hay que decir que la música de Falla se adaptó perfectamente a los cánones impresionistas gracias al conocimiento del acervo popular, ya que los propios Debussy y Ravel tomaron elementos de la tradición folklórica española para dar un nuevo viraje a la composición musical, no en vano, la guitarra fue considerada como un instrumento netamente impresionista.

Así pues Falla será el máximo representante del Impresionismo primero y del Neoclasicismo después, pero, insisto, Falla luchará por hacer una modernidad conectada con Europa pero no dependiente exclusivamente de ella, acudiendo al repertorio popular como esa distinción estética por recuperar. Esta voluntad consciente de trabajar en un modelo renovador personal definirá la intencionalidad de todo el grupo vinculado con el Veintisiete, de ahí también ese deseo de interrelación artística.

Este mismo intento es el que encontramos en, por ejemplo, la famosa Escuela de Vallecas, conformada fundamentalmente por Benjamín Palencia y Alberto Sánchez, a la que se pueden añadir los nombres de Maruja Mallo o Federico García Lorca. Esta Escuela, donde se registra un importante componente surrealista -pensemos que el surrealismo definirá a buena parte de los escritores, pintores y cineastas del 27 , otra cosa será el ámbito musical- arrancaría de aproximadamente 1927, momento entonces en el que muchos de nuestros creadores fueron a París con el fin de hallar otros cauces para el arte nuevo. Palencia y Sánchez se quedan en España, querrán trabajar en la modernidad pero buscando un arte nacional, que no nacionalista, y su recurso fue el de ir a la tierra, a lo popular, y lo hallarán en los 
alrededores del Madrid digamos menos famoso. Frente a la zona norte de la Sierra que tan encumbrada había sido por la Sociedad de Excursiones o la Institución Libre de Enseñanza, se gira los ojos hacia lo olvidado, hacia el páramo, en sus tierras y en sus gentes se halla el mejor recurso para el surrealismo, se hacen composiciones a partir de guijarros, de tierras, se busca la modernidad en lo primitivo.

Por otra parte, esta búsqueda de la modernidad en lo popular y primitivo por parte del Veintisiete, se vincula plenamente con la vanguardia europea, recordemos en este sentido la importancia que para el nacimiento del Cubismo o el desarrollo del Expresionismo tuvieron la escultura ibera o el arte africano.

El gusto que la producción estética de aquellos años mostrará por nuestras raíces irá de la mano de esa misma querencia en el campo científico. Me explico, cuando hablamos del grupo del 27 no sólo nos debemos reducir a una importante nómina de artistas y creadores, también debemos citar a científicos, teóricos y críticos que con sus escritos difundirán y divulgarán nuevas inquietudes. Como ha señalado el musicólogo Casares Rodicio, si por algo destacó el 27, fue por insertar la música y a los músicos en la órbita intelectual, e incluso se consiguió que desde el Estado, ya con la II República, se constituyese una Junta Nacional de Música compuesta por Bacarisse, Salazar, Ernesto Halffter y Óscar Esplá. El Decreto de fundación justifica su organización aludiendo a que un país moderno y con dictados de progreso se deben mantener e incentivar los valores de la música, por tanto se entiende la música como un arte constitutivo del estado democrático, ética y estética van de la mano ${ }^{10}$.

Precisamente, por ahora y al hilo de este cientifismo musical, es cuando inicia su andadura el Centro de Estudios Históricos de la mano del musicólogo Martínez Torner, institución dependiente de la famosa Junta de Ampliación de Estudios que por entonces presidía Ramón y Cajal. Pues bien, Martínez Torner se dedicará a recopilar cantos y melodías de diversos lugares de España, como León y Asturias.

Su experiencia no fue algo aislado, ahí tenemos a Lorca recopilando cantos o nanas de las que en muchos casos él hacía la trascripción y que en tantas ocasiones interpretaba en el piano para acompañar a la Argentinita, cantante dilecta del grupo del 27. Aquellos cantantes y cantaores se convierten en figuras que se relacionan con la intelectualidad, por ser portadores de ese acervo popular tan admirado por los artistas y la intelectualidad del 27. Lorca quizá pueda ser uno de los mejores representantes de esta convivencia artística del 27 , ya que además de poeta y dramaturgo también fue músico ${ }^{11}$. Buen interprete de piano, eran frecuentes sus recitales en la Residencia de Estudiantes, además de musicar un gran repertorio de nuestro cancionero popular. A ello hay que añadir su dedicación al dibujo, unos dibujos

10 CASARES RODICIO, E.: “Música y músicos de la Generación del 27”, en La Música en la Generación del 27, Madrid, Ministerio de Cultura, 1986, págs. 32 y ss.

11 Testimonio directo de la gran afición y estudio musical de García Lorca son obras como El poema del Cante Jondo o sus conferencias dedicadas a la Arquitectura del Cante Jondo o las Nanas, obras todas ellas recopiladas en GARCÍA LORCA, F.: obras completas (30 vols.), Madrid, RBA, 1998. Sobre García Lorca y la música ver: GIBSON, I.: "Lorca y la música”, en La Música en la Generación del 27, Madrid, Ministerio de Cultura, 1986, págs. 81 y ss. 
que trasvasaban sus inquietudes artísticas y en general los programas estéticos de esta Generación, de ahí que hallemos creaciones gráficas de honda raíz popular en un primer momento hasta llegar a imágenes claramente surrealistas. Muchas veces estos dibujos se inspiran en coplas y letras de la tradición oral cantada, al igual que sucedía en su poesía.

Pero en Lorca también hay un afán de estudio, de sistematización, de ahí que hallemos entre sus conferencias las dedicadas a la Arquitectura del Cante Jondo o a las Nanas. Evidentemente, la difusión de estos repertorios y su estudio, serán un componente más para entender el neopopularismo que invadió la producción de la vanguardia española por ahora. Una de las músicas populares que más atraerá al 27 , será el flamenco. No hay que olvidar que buena parte de la Generación del 27 está compuesta por artistas y escritores que provienen del sur, por lo que ya estaban familiarizados y admiraban estas formas, aquellas letras, ese duende, parafraseando a Lorca.

Por otra parte, el estudio de aquellas formas heredadas, puras, era retomar algo del primitivismo no contaminado, que tan importante como hemos visto es para el arte contemporáneo, ya lo he referido en torno al Cubismo, como lo había sido de igual modo para el propio P. Gauguin o Van Gogh, pero también para el surrealismo, Breton y sus acólitos reclamarán la creación primitiva como una forma primigenia de arte. Pues bien, los jóvenes veintisietistas van a hallar este primitivismo renovador en el cante jondo.

En buena medida a Lorca y Falla, pero también a Rusiñol o Zuloaga, recordemos que estamos en tiempo de convivencia intergeneracional, se debe la revalorización del cante jondo. Es más, el concepto del Flamenco como música culta que a día de hoy tenemos viene a partir del rescate que de él hicieron Falla y García Lorca. Pero el cante jondo no sólo será un recurso, una influencia en las estéticas de ambos artistas, sino que lucharán activamente por dar a conocer estos repertorios. Así pues en junio de 1922, con motivo de las Fiestas del Corpus Christi de Granada, organizan el ya célebre Concurso de Cante Jondo.

El cartel lo efectúa el buen amigo y asiduo colaborador de Manuel de Falla y Lorca, Manuel Ángeles Ortiz. En dicha obra se condensa buena parte de la estética pictórica, literaria y musical de aquel momento: formas cubistas para albergar motivos netamente hispanos, como puede ser el Corazón de la Virgen de los Dolores -Virgen de las Angustias Patrona de Granada-, la guitarra, etc. A este festival acudió lo más granado de la intelectualidad española, siendo todo un referente desde entonces.

Quizá uno de los lugares que pueden resumir como pocos el diálogo entre las Musas, la relación entre las artes pero también de los estudios científicos, fue la institución por antonomasia de la Generación del 27, la Residencia de Estudiantes. Dicha institución, siguiendo escrupulosamente las ideas de su director, Alberto Jiménez Fraud, iba encaminada a la formación de una clase intelectual a través del trabajo interdisciplinar.

Aunque en muchos esta Residencia se ha conocido exclusivamente por ser el lugar de encuentro entre Buñuel, Lorca y Dalí -lo que ya es un hito-, lo cierto es 
que su influencia fue mucho más allá, pues además de su insignes residentes, entre los que estaban el propio J. Ramón Jiménez, Manuel Ángles Ortiz, Prados, etc., la Residencia era lugar de reunión abierta al público y por donde pasaron los miembros más destacados de la intelectualidad y el arte español e internacional, entre su conferenciantes estuvieron: A. Einstein, Mme. Curie, Chesterton, Louis Aragon, Paul Valery, no olvidemos que en la Residencia también estará el germen del surrealismo, movimiento este que también definirá en buena medida a muchos de los veintisietistas por lo que literatura y pintura se refiere.

En la Residencia dieron conferencias y conciertos Falla, Stravinsky, Poulenc, Ravel. La música era un objetivo esencial en la formación de aquellos estudiantes y, por tanto, un componente más en el acervo cultural de esos artistas y literatos en ciernes $^{12}$. La música era un elemento cotidiano, Moreno Villa ha referido como era común mientras él pintaba, escuchar la música siempre de fondo, bien a través de algún gramófono o de algún estudiante que tocaba el piano del salón o la guitarra. Música también imprescindible en las actuaciones y pequeñas obras de teatro que se efectuaban allí, obras que en muchos casos retomaban a nuestros clásicos, como el célebre don Juan Tenorio.

Acabo de hablar de clásicos, y lo cierto es que el 27 busca la modernidad en nuestro pasado popular, pero también en nuestro pasado culto, no en vano, el hecho que ha dado nombre a este grupo es precisamente el homenaje brindado en el Ateneo de Sevilla a Góngora en el tricentenario de su nacimiento.

A propósito del homenaje a Góngora, hay que señalar lo frecuente que en este momento eran las reuniones de artistas de diversas disciplinas en torno a una lectura de poemas, de un homenaje o alrededor de la mesa de una tertulia, actividades conjuntas que nos revelan una franca camaradería y una clara intención de interrelación en la búsqueda de una estética determinada.

Retomando la experiencia estética generada por nuestros clásicos, en este momento, los creadores del arte nuevo girarán su mirada hacia ellos, reconociéndose en sus obras el germen de la modernidad. No olvidemos el contexto europeo, España con el 27, se inserta en esa línea de vanguardia que supone el Retorno al Orden característico de la Europa de este momento, los clásicos vistos con ojos modernos. Muchas experiencias literarias, musicales y pictóricas quedarán marcadas por esa nueva mirada sobre los clásicos. En primer lugar hay que hablar del famoso número que la revista malagueña Litoral -dirigida por M. Altolaguirre y $\mathrm{E}$. Prados- dedicó como homenaje a Góngora, un número que desde luego sirve de acta notarial de los componentes. Junto a todos los poetas más representativos de la Generación de 27 -L. Cernuda, R. Alberti, V. Aleixandre, M. Altolaguirre, R. Buendía, G. Diego, F. García Lorca, E. Frutos, P. Garfias, J. Guillén, A. Valle, J. Moreno Villa, Quiroga y Plá-, se insertaron los trabajos de algunos artistas de plena

12 PERSIA, J. DE: "La música en la Residencia de Estudiantes”, en La Música en la Generación del 27, Madrid, Ministerio de Cultura, 1986, págs. 47-63. 
vanguardia, y que bien representan la comunión estética ideológica a la que vengo aludiendo a lo largo de esta intervención: B. Palencia, Togores, Moreno Villa, S. Dalí, Ucelay, junto a reproducciones de Picasso, Fenosa, Ángeles Ortiz, Cossío, Peinado, Huguet, H. Viñes, Bores y J. Gris.

También participó Falla, que, a petición de Prados, Hinojosa y Altolaguirre, publicó los primeros compases de su Soneto a Góngora, por tanto vemos a Falla una vez más plenamente inserto en el 27.

Litoral, principal órgano difusor del 27, era punta de lanza de una serie de revistas de vanguardia que en realidad acampaban por toda nuestra geografía. En este sentido, por aquellos años se llegará a una brillantez extraordinaria por lo que a este tipo de publicaciones se refiere. Dichas revistas serán decisivas en la difusión del nuevo arte y un elemento esencial para entender, una vez más, esa necesidad conjunta de elaborar una estética de evidente proyección social. Gaceta de Arte en Madrid, Gayo en Granada, Litoral en Málaga, Verso y Prosa en Murcia o Alfar en La Coruña, recogerán en sus páginas las creaciones de los más brillantes poetas y literatos del momento, poetas que en muchos casos hacían crítica de arte, así como también había lugar para ilustraciones de diversos artistas ${ }^{13}$.

La música por supuesto también tuvo su lugar y así las plumas de Ball y Gay o Adolfo Salazar, éste último fundamental en el desarrollo de la música de vanguardia en nuestro país, así como para la referida proyección intelectual y social de la música, pudieron dar a conocer sus ideas y estudios a través de estos órganos.

Volviendo a la impronta de lo clásicos, ésta quedará patente de igual manera en experiencias como La Barraca, la compañía de teatro dirigida por García Lorca, cuyo fin era el de mostrar nuestros clásicos por las regiones y pueblos cuyo acceso a la cultura era precario. El repertorio estaba compuesto por obras de Calderón o de Lope de Vega, y como era habitual en estas obras se contaba con los correspondientes interludios musicales y danzas. En muchos casos el propio Lorca rescataba y musicaba repertorio popular. Estas obras además estaban decoradas por escenarios y figurines efectuados por artistas como Benjamín Palencia, Alberto Sánchez o Manuel Ángeles Ortiz, decorados donde se integraba perfectamente la vanguardia con aquellas obras a las que servía de fondo, quienes a su vez también colaboraban con las Misiones Pedagógicas, insigne proyecto cultural de la II República, que también llevaban la cultura -teatro, pintura, música- por toda nuestra geografía, pero también se ocupaban de recopilar costumbres ancestrales para evitar su pérdida y olvido.

También hallamos influencias populares y de nuestros clásicos, de igual modo, habrá interludios musicales compuestos por el propio poeta y además encontraremos carteles y escenografías efectuados por artistas como Juan Antonio Morales o Caballero.

Donde podremos hallar de una forma más directa el diálogo entre Musas será en las artes escénicas, pues aquí, música, literatura, poesía, pintura y diseño serán

13 AA.VV., Arte moderno y revistas españolas: 1898-1936, Madrid, Museo Nacional Centro de Arte Reina Sofía, 1996; BRIHUEGA, J., Las vanguardias artísticas en España, Madrid, Istmo, 1981. 
todo uno para crear y recrear esa tan anhelada obra de arte total. Contamos con buenos ejemplos de la vanguardia europea donde se mostraba una especial preocupación por unir a grandes artistas en producciones de ballets, destaca en este sentido, por ejemplo, el famoso Ballet Mecánico de George Antheil con figurines de Fernand Leger y escenografía de Jean Arp, que se estrenó en París en 1925.

Pero sin duda los espectáculos de este tipo que generaron una gran expectación durante los años diez y veinte, fueron los famosos ballets Rusos de Diaghilev, que estaban haciendo furor por sus giras europeas. Diaghilev llevaba a escena sin escatimar ningún tipo de detalle ni lujo los repertorios de artistas la vanguardia musical y artística, como Stravinsky, Falla o Picasso.

Por lo que a nosotros nos interesa, hay que citar el gran éxito registrado por El Sombrero de Tres Picos, que estrenada en su versión para Ballet en 1919, contó con decorados y figurines de Picasso, comentando la crítica la modernidad de ambos. Falla quedó tan satisfecho con estos decorados, que con el fin de que se pudiera admirar el primer telón, el maestro gaditano insertó en la obra las fanfarrias iniciales, por tanto hay una adaptación de la escenografía a la música y el libreto, pero también la música se adapta a la escena.

Picasso recurrió para esta puesta en escena a los repertorios dieciochescos, ello no es extraño, en primer lugar porque el libreto se basa en la obra homónima de Ruiz de Alarcón, pero es que, además, en este momento la música española y Falla en concreto mirará con intensidad al siglo XVIII, por hallar en sus repertorios esa pureza que estoy refiriendo como característica del retorno al orden. Este es un lugar común también en otros artistas, pensemos en las Goyescas de Enrique Granados.

Desde el punto de vista musical se recuperará al Padre Soler, a Scarlatti y la zarzuela del XVIII. Con Falla entra igualmente en España el Neoclasicismo, esa variante musical del Retorno al Orden, no en vano también nos encontramos ante la llamada fase neoclásica de Picasso, quien también mirará al XVIII, concretamente a Ingres para crear unos nuevos postulados artísticos basados en la pureza lineal. Lorca también dibuja majos y majas goyescas.

Con el Retablo de Maese Pedro y el Concierto para clavicémbalo, irrumpe el Neoclasicismo musical en España. No obstante como ha señalado Casares Rodicio, para la difusión de esta tendencia estética fue también esencial la influencia neoclásica literaria del $27^{14}$.

En este sentido, no menos importante sería el contacto y amistad de Falla con Stravinsky, quien además viajó con relativa frecuencia a nuestro país. Pero en general para el desarrollo del neoclasicismo musical es esencial entender el París de los años veinte, el París de Cocteau o Satie, marcado por la diversión, lo grotesco y lo burlesco, este hecho convertirá las grandes formas musicales en otras más "recoletas", tales como sonatinas y sinfonietas ${ }^{15}$.

14 CASARES RODICIO, E.: op. cit., págs. 25-32.

15 Ibídem. 
Esta marcada tendencia por el divertimento la hallamos con igual intensidad en pintura, de hecho, es muy común el tema de la alegría y las fiestas entre los pintores vinculados al Veintisiete, representado fundamentalmente por la verbena, tema este tratado por pintores de plena vanguardia como Rafael Barradas, y, sobre todo, por Maruja Mallo, quien realiza varias obras dedicadas a este tema, cuadros herederos del neocubismo y del collage, donde inserta elementos característicos de las ferias y verbenas, pero también elementos de la vida moderna como era el deporte. Sabemos que los veintisietistas amantes de lo popular lo eran también de las verbenas, son muchos los testimonios gráficos y escritos de los jóvenes del 27 paseando y disfrutando por las estas fiestas populares, buen testimonio es la película de vanguardia Esencia de verbena (1930) de Giménez Caballero.

En este sentido, hay que citar la cultura y el arte norteamericano, pues de forma paralela, especialmente en su música, se registra de igual modo esta integración popular como una imagen de vida alegre y desenfadada, caso claro es el Gershwin y el jazz. Por cierto que hasta la Residencia de Estudiantes también llegaba el jazz, especialmente en los cursos de verano, sabemos que el propio Buñuel era muy aficionado a estos repertorios.

De alguna manera el peculiar mosaico que componen las influencias y experiencias comunes de las diferentes artes en un mismo tiempo -el 27-, se pueden condensar en la puesta en escena del Retablo de Maese Pedro de Manuel de Falla, cuyo estreno privado tuvo lugar en 192516. Una vez más el maestro gaditano tuvo la capacidad de aglutinar a los más jóvenes en un proyecto nuevo.

El tema en sí mismo supone una revisión de nuestros clásicos, de hecho, se basa en nuestro clásico por excelencia, pues se inspira en el capítulo XXVI de la segunda parte de El Quijote. Dentro de ese proceso de depuración que la vanguardia vivía por ahora, dicha obra se configura a modo de ópera de cámara para tres voces, Don Quijote barítono, el Trujamán, niño o soprano y Maese Pedro, tenor. Desde el punto de vista musical podemos decir que Maese Pedro, suponía la puesta de largo del Neoclasicismo musical en nuestro país, para ello recurre a repertorios del XVIII, pero también a la tradición polifónica española. No menos importante será la tradición popular como los pliegos de cordel o el folklore. A ellos le acompañaba su puesta en escena, retomando la vieja tradición de los títeres.

Esta experiencia también es producto de la convivencia de los intelectuales del Veintisiete en Granda, sabemos que en torno al café de la Alameda, Falla, Lorca, Manuel Ángeles Ortiz proyectaban hacer teatros de títeres basándose en las cantigas de Alfonso $X$, recitaban el Romancero. De hecho, poco antes de que Falla concluyese esta obra, en casa de los García Lorca se representó el día de Reyes un auto realizado con títeres.

Así pues Hermenegildo Lanz se encargó de labrar las cabezas de los títeres y

16 Para el estudio de la música y la relación entre las artes que hallamos en el Retablo de Maese Pedro, ver: BONET, J. M.: Manuel de Falla y Manuel Ángeles Ortiz. El Retablo de Maese Pedro, Madrid, Residencia de Estudiantes, 1996. 
Manuel Ángels Ortiz de hacer escenografías y figurines, en los que también interviene Hernando Viñes. El atrezo aunaba las formas neocubistas con maneras más tradicionales.

Admirada y elogiada por músicos como Stravinsky, esta obra, tras su estreno parisino, se llevó a cabo en diferentes lugares como Madrid, Sevilla, Granada, en los estudios de la BBC de Londres, en la Opera Comique de París -en este caso con figurines y decorados de Zuloaga- o Amsterdam, siendo el director de escena Luis Buñuel. 